\title{
КАДАСТРОВЫЙ И БУХГАЛТЕРСКИЙ УЧЕТ ОБЪЕКТОВ НЕДВИЖИМОСТИ
}

\section{Анастасия Леонидовна Ильиных}

Сибирский государственный университет геосистем и технологий, 630108, Россия, г. Новосибирск, ул. Плахотного, 10, кандидат технических наук, доцент кафедры кадастра и территориального планирования, тел. (383) 344-31-73, e-mail: ilinykh_al@mail.ru

\section{Яна Сергеевна Скрылева}

Сибирский государственный университет геосистем и технологий, 630108, Россия, г. Новосибирск, ул. Плахотного, 10, обучающийся, e-mail: yana.tishhenko.95@mail.ru

Вопросы кадастрового и бухгалтерского учета объектов недвижимости важны для российских организаций, так как в составе активов многих из них такие объекты занимают значительную долю. Некорректный учет объектов недвижимости существенно искажает финансовую отчетность российских компаний и вводит в заблуждение заинтересованных пользователей. Объекты недвижимости - особые товары. В первую очередь, это связано с тем, что право собственности и другие вещные права на них, ограничение, возникновение, переход и прекращение этих прав подлежат государственной регистрации в Едином государственном реестре недвижимости после их кадастрового учета. При этом, права на имущество, подлежащие государственной регистрации, возникают с момента их регистрации.

Ключевые слова: кадастровый учет, бухгалтерский учет, основные средства, активы, объект недвижимости

\section{CADASTRAL ACCOUNTING AND ACCOUNTING OF REAL ESTATE OBJECTS}

\section{Anastasia L. Ilyinykh}

Siberian State University of Geosystems and Technologies, 10, Plakhotnogo St., Novosibirsk, 630108, Russia, Ph. D., Associate Professor, Department of Cadastre and Territorial Planning, phone: (383) 344-31-73, e-mail: linykh_al@mail.ru

\section{Yana S. Skryleva}

Siberian State University of Geosystems and Technologies, 10, Plakhotnogo St., Novosibirsk, 630108, Russia, Student, e-mail: yana.tishhenko.95@mail.ru

Cadastral and accounting issues real estate objects are important for Russian organizations, since such objects occupy a significant share in the assets of many of them. Incorrect accounting of real estate objects significantly distorts the financial statements of Russian companies and misleads interested users. Real estate objects - special goods. First of all, this is due to the fact that the right of ownership and other real rights to them, the restriction, occurrence, transfer and termination of these rights are subject to state registration in the unified state real estate register after their cadastral accounting. At the same time, the rights to property subject to state registration arise from the moment of their registration, unless otherwise established by law.

Keywords: cadastral accounting, accounting, fixed assets, assets, real estate object 
Кадастровый и бухгалтерский учет недвижимости находятся в сфере интересов юридических лиц (предприятий).

Недвижимое имущество - это земельные участки, участки недр и все объекты, которые связаны с землей так, что их перемещение без несоразмерного ущерба их назначению невозможно, в том числе здания, сооружения, жилые и нежилые помещения, предприятия как имущественные комплексы [1].

Организация, имеющая в собственности обособленное имущество, должна обладать самостоятельным балансом и сметой. Бухгалтерский баланс, представляющий собой официально установленную форму отчета учета, полученного в процессе хозяйственной деятельности и гражданского оборота имущества юридического лица, является источником юридически значимой информации [1].

Сам по себе учет объектов недвижимости в бухгалтерии имеет свою специфику. Существует ряд мероприятий, которые проводят с данными объектами. Необходимо проводить действия по государственной регистрации прав на недвижимое имущество, а перед этим - кадастровых работ и постановку на кадастровый учет земельных участков, на которых расположены данные объекты, как показано на рис. 1 [1-4].

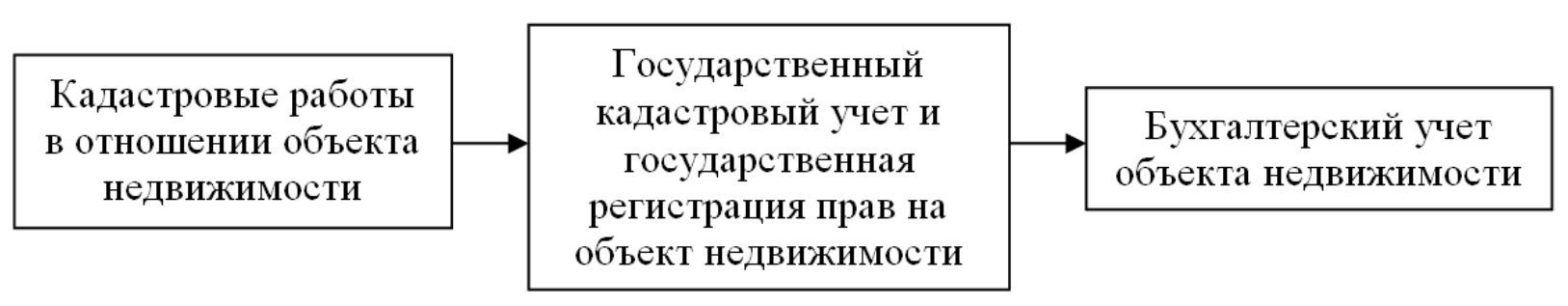

Рис. 1. Учет недвижимости в организации

Действия, которые связанны с государственной регистрацией недвижимого имущества, в обязательном порядке подлежат отражению в бухгалтерском учете. Также, в свою очередь, они влияют на порядок осуществления бухгалтерских операций в отношении недвижимого имущества, в частности, на формирование и образование бухгалтерской стоимости объектов, учета износа, начисления амортизации. В Российской практике объекты недвижимости классифицируются в качестве основных средств. В бухгалтерском балансе они отражаются на счете 01 "Основные средства". Фрагмент баланса представлен в табл. 1.

Таблий 1

Фрагмент из бухгалтерского баланса организации

\begin{tabular}{|l|c|c|}
\hline \multicolumn{1}{|c|}{ Наименование показателя } & Код & На 31 декабря 2020 г. \\
\hline АКТИВ & & \\
\hline 1 ВНЕОБОРОТНЫЕ СРЕДСТВА & & \\
\hline$<\ldots>$ & & \\
\hline Основные средства & 1150 & - \\
\hline
\end{tabular}


Существует ряд нормативно-правовых документов, на основании которых осуществляется бухгалтерский учет объектов недвижимого имущества в качестве основных средств. Данные правовые документы указаны на рис. 2 [4].

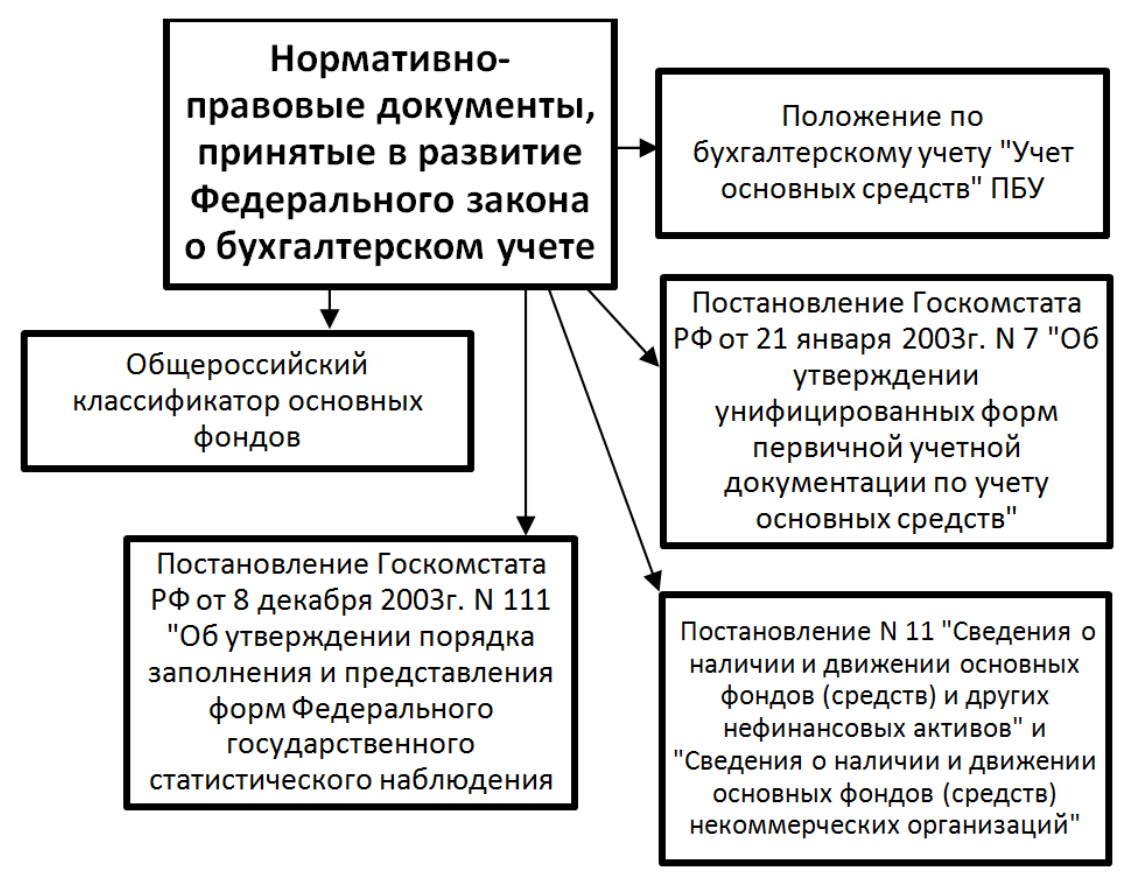

Рис. 2. Нормативно-правовые документы, принятые в развитие Федерального закона о бухгалтерском учете

Согласно положению о бухгалтерском учете, актив принимается организацией к бухгалтерскому учету в качестве основных средств, если соблюдаются следующие условия, показанные на рис. 3 [5].

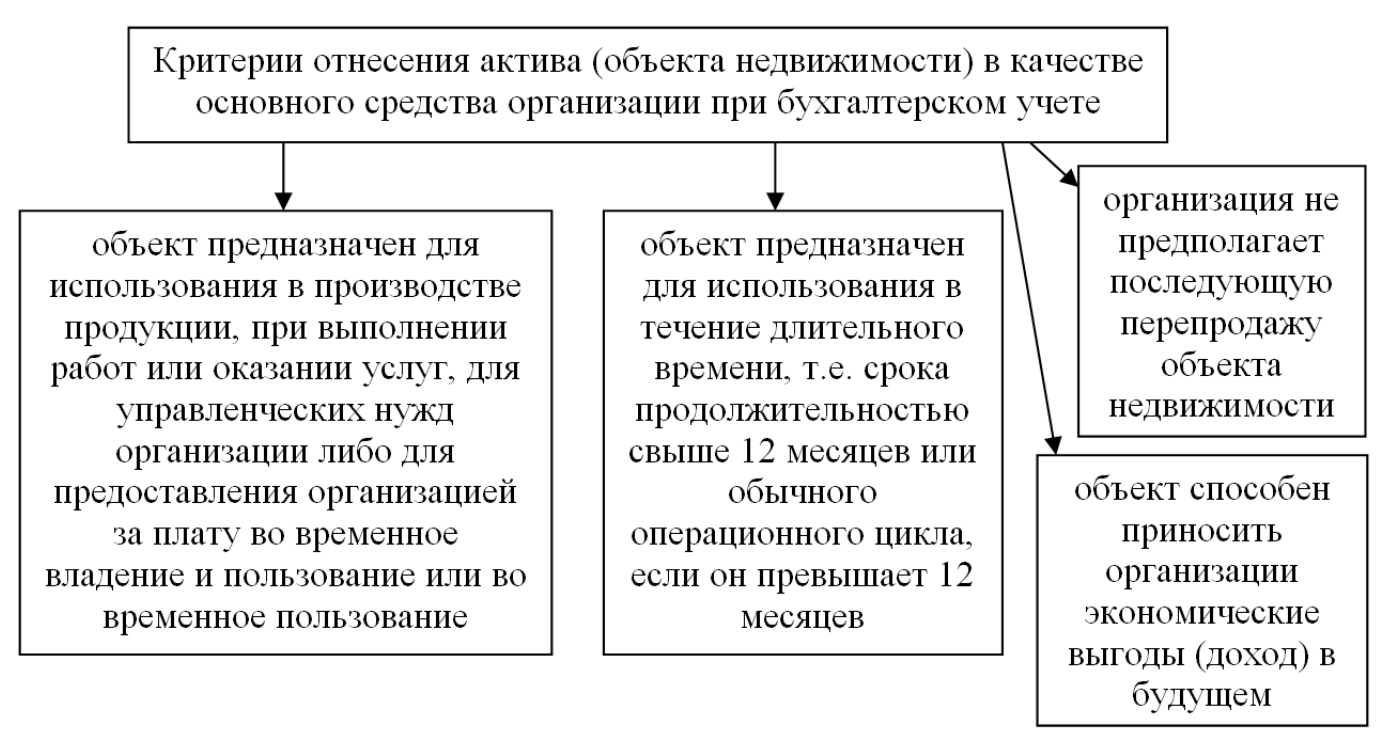

Рис. 3. Критерии отнесения объекта недвижимости как актива в качестве основного средства организации при бухгалтерском учете 
Организация, получившая объект недвижимости, права собственности на который подлежат кадастровому учету и государственной регистрации, должна принять его к бухгалтерскому учету в качестве основного средства, независимо от факта государственной регистрации прав собственности [6]. В бухгалтерском учете коммерческой организации составляется ряд записей или бухгалтерским языком «проводок». Пример такой бухгалтерской проводки представлен в табл. 2.

Таблиия 2

Бухгалтерская проводка «Учет объекта недвижимости в организации»

\begin{tabular}{|l|l|}
\hline Дебет & Кредит \\
\hline $\begin{array}{l}\text { 08 счет } \\
\text { «Вложения во внеоборотные активы» }\end{array}$ & 60 счет \\
& «Расчеты с поставщиками и подряд- \\
& чиками»- отражена покупная стои- \\
& мость здания без НДС на дату пере- \\
& хода права собственности \\
\hline $\begin{array}{l}19 \text { счет } \\
\text { «Налог на добавленную стоимость } \\
\text { по приобретенным ценностям». }\end{array}$ & 60 счет \\
\hline $\begin{array}{l}\text { 01счет } \\
\text { «Основные средства» }\end{array}$ & «Расчеты с поставщиками и подряд- \\
& чиками»- «входной» НДС по сделке. \\
\hline & «Вложения во внеоборотные активы» \\
& - учтена стоимость здания в составе \\
& основных средств на дату акта при- \\
& емки-передачи. \\
\hline
\end{tabular}

Рассмотрим, каким образом происходит приобретение объектов недвижимого имущества в организации. Основные средства принимают на бухгалтерский учет по первоначальной стоимости. Под первоначальной стоимостью понимается сумма фактических затрат организации на приобретение, сооружение и изготовление. Исключением является такие факторы, как: НДС и иных возмещаемых налогов, в том числе суммы, уплачиваемые в соответствии с договором поставщику (продавцу), а также суммы, уплачиваемые за доставку объекта и приведение его в пригодное для использования состояние [6].

Существуют специальные унифицированные формы первичной учетной документации, которые организации используют для отражения объектов основных средств в бухгалтерском учете - формы ОС-1а «Акт (накладная) приемки передачи основных средств» [4].

Помимо приобретения объектов недвижимого имущества, организация может так же взять в аренду такие объекты. Согласно плану счетов бухгалтерского учета финансово-хозяйственной деятельности организации [7], арендованные основные средства учитываются на забалансовом счете 001 "Арендованные основные средства".

Арендованные объекты недвижимости, включая земельные участки, отражают в бухгалтерском учете на основании документов, показанных на рис. 4 [8]. 




Рис. 4. Документы-основания для бухгалтерского учета арендованных объектов

Итак, процедура постановки недвижимого имущества на кадастровый учет не зависит от процедуры постановки объектов на бухгалтерский учет в организации. При этом, процедура постановки на кадастровый учет по времени происходит гораздо быстрее и осуществляется в более ранние сроки, чем отражение объекта в бухгалтерском учете организации.

\section{БИБЛИОГРАФИЧЕСКИЙ СПИСОК}

1. Гражданский кодекс Российской Федерации. Часть 1 от 30 ноября 1994г. №51-Ф3 // Собрание законодательства Российской Федерации. 1994. - №32. - Ст. 3301; Гражданский кодекс Российской Федерации. Часть 2 от 26 января 1996г. №14-Ф3 // Собрание законодательства Российской Федерации. 1996. - №5. - Ст. 410.

2. Клюшниченко В. Н., Ивчатова Н. С. Особенности формирования кадастра в России// Вестник СГУГиТ. - 2020. -Т. 25, № 2 - С. 198-208.

3. Байков К.С., Гаврюшина Н.В., Ильиных А.Л. Особенности государственного кадастрового учета отдельных видов сооружений // Изв. вузов «Геодезия и аэрофотосъемка». - 2013. №4/C. - С. 175-179.

4. Положение по бухгалтерскому учету "Учет основных средств" ПБУ 6/01 [Электронный ресурс]: приказ Министерства финансов РФ от 30.03.2001 N 26н. - Доступ из справ.-правовой системы «КонсультантПлюс». - Загл. с экрана.

5. Общероссийский классификатор основных фондов [Электронный ресурс]: постановление Государственного комитета Российской Федерации по стандартизации, метрологии и сертификации от 26 декабря 1994г. N 359, в ред. Изменения 1/98, утв. Госстандартом РФ 14.04.98. - Доступ из справ.-правовой системы «КонсультантПлюс». - Загл. с экрана.

6. Об утверждении унифицированных форм первичной учетной документации по учету основных средств [Электронный ресурс]: постановление Госкомстата РФ от 21.01.2003г. №7. Доступ из справ.-правовой системы «КонсультантПлюс». - Загл. с экрана.

7. Бадулина Е.В. Федеральный закон о государственной регистрации недвижимости: предпосылки принятия и некоторые новеллы // Имущественные отношения в Российской Федерации. 2015. № 10 (169). С. 6-15.

8. Белоконов А.В., Лигай В.О. Понятие, содержание и сущность государственной регистрации прав на недвижимое имущество // Ученые труды Российской академии адвокатуры и нотариата. 2015. № 3 (38). С. 127-132. 